\title{
Implementation of Salibu Rice Cultivation Technology in Percut Sei Tuan Sub-District
}

\author{
Syarifa Mayly ${ }^{*)}$ and A. Syafri
}

Faculty of Agriculture, Program of Study Agroecotechnology, University of Al Washliyah Medan

\begin{abstract}
Percut Sei Tuan Sub-district is an agricultural production center in Deli Serdang Regency. The area of irrigated paddy field in Percut Sei Tuan Sub-district comprises of 3,610 ha and 1,616 ha of non-irrigated paddy field. The farmer association groups (tani mitra) consisting of Farmer Group "Pasar II" and Farmer Group "Mulia" are located in Tanjung Selamat Village. Much land in Tanjung Selamat Village has been converted into an industrial area; previously the paddy field area reached 600 hectares, but only 200 hectares remains now. The Farmer Groups "Pasar II" and "Mulia" consist of 30 and 76 farmers with paddy rice field area of 25 ha and 23 ha respectively, and rice productivity amounts to 6.2 tons/ha and 7 tons/ha. The problems of the farmers were the high land use conversion resulting in reduced harvested area and only a few farmers change the local location-specific organic materials into organic fertilizers independently. The purposes of this community service activity were to increase the farmers' income through the implementation of salibu technology whereby farmers can harvest 2-3 times in one planting and to increase the farmers' understanding and knowledge about the manufacturing process of organic fertilizer and pesticide. The solutions offered were including counseling, a training and plot demonstration on salibu technology, and the production of bokashi straw. The outcome of this IbM has resulted in several things: bokashi of compressed hay with Local Microorganism from cattle intestine and Trichoderma, organic pesticide products based on Corynebacterium and Trichoderma, and farming analysis with salibu technology.
\end{abstract}

Keywords: Bokashi, Paddy, Organic Pesticide, Salibu

Abstrak. Kecamatan Percut Sei Tuan adalah sentra produksi pangan di Kabupaten Deli Serdang. Luas lahan padi di Kecamatan Percut Sei Tuan yang memiliki irigasi 3.610 ha dan non irigasi 1.616 ha. Kelompok tani mitra yaitu kelompok tani "Pasar II" dan Kelompok Tani “Mulia” berada di desa Tanjung Selamat. Lahan di desa Tanjung Selamat banyak beralih fungsi sebagai kawasan industri dimana awalnya lahan sawah mencapai 600 hektar, sekarang tinggal 200 hektar. Kelompok tani "Pasar II" dan "Mulia” memiliki jumlah anggota 30 dan 76 petani, luas areal persawahan masing-masing 25 dan 23 ha, dengan produktivitas padi mencapai 6,2 ton/ha dan 7 ton/ha. Permasalahan mitra yaitu *Corresponding author at: Jalan Sisingamangaraja No. 10 Medan, Indonesia

E-mail address:syarifamayly@yahoo.com 
besarnya alih fungsi lahan mengakibatkan berkurangnya luas panen dan petani masih sedikit yang mengubah bahan organik lokal spesifik lokasi menjadi pupuk organik secara mandiri. Tujuan kegiatan pengabdian kepada masyarakat yaitu untuk meningkatkan pendapatan petani melalui penerapan teknologi Salibu dimana petani dapat panen 2-3 kali dalam satu kali penanaman serta meningkatkan pemahaman dan pengetahuan petani tentang pembuatan pupuk dan pestisida organik. Solusi yang ditawarkan yaitu melakukan penyuluhan, pelatihan serta demonstrasi plot tentang teknologi salibu dan pembuatan bokhashi jerami. Luaran dari $I_{b} M$ ini sudah menghasilkan beberapa hal : bokhasi jerami yang sudah dikomposkan dengan MOL dari usus sapi dan Trichoderma, produk pestisida organik yang berbahan dasar Corynebacterium dan Trichoderma, analisa usaha tani dengan teknologi salibu.

Kata Kunci : Bokashi, Padi, Pestisida Organik, Salibu

Received 6 November 2017 | Revised 10 January 2018 | Accepted 13 February 2018

\section{Introduction}

National rice demand continues to increase as the population grows while the conversion of productive paddy fields to non-agricultural sectors is difficult to halt [1]. Pramono stated that the paddy field area has been reduced by 1,226 ha or $0.51 \%$ in the period of 2006-2014 [2]. The type of paddy fields that were converted and sold were rain-fed paddy fields by 53\% and irrigated rice fields by $47 \%$. The paddy field conversion to another commodity was influenced by poor irrigation at $73 \%$ and easier cultivation technique of the replacement commodity at $27 \%$.

Efforts to increase national rice production are carried out by implementing several strategies including: 1) the expansion of planting areas by creating new paddy fields, 2) increasing the land productivity, and 3) expanding the harvest area through increasing the harvest index.

Salibu technology is one of the technological innovations to boost productivity or to increase rice production by increasing the harvest index. The cultivation of salibu rice can increase the land productivity through increasing the harvest index from 2 to 3 or even 4 times of harvests in one year. Research results of Erdiman showed that the yields of rice from local varieties in Matur, Agam Regency was 7.2 tons per hectare with $102 \mathrm{~cm}$ in height, 22 tillers, $24 \mathrm{~cm}$ panicle length, 120 grains per panicle, and only $17 \%$ of empty grain [3].

Deli Serdang Regency is one of the third largest rice producing centers in North Sumatra after Simalungun and Langkat Regency which can be seen from the harvested area, the production, and the productivity in 2013 were 80,104 ha, 419,818 tons and 5,62 tons/ha respectively (BPS Sumut, 2016). Percut Sei Tuan Sub-district consists of 20 villages which is located at coordinates $2^{\circ} 57^{\prime}-3^{\circ} 16^{\prime} \mathrm{NL} 98^{\circ} 33^{\prime}-99^{\circ} 27^{\prime} \mathrm{EL}$ with a total area of 2,394.62 $\mathrm{km}^{2}$. It has a 
tropical climate with temperature ranging from $13^{\circ} \mathrm{C}-38^{\circ} \mathrm{C}$ and average rainfall at around 243 $\mathrm{mm} /$ year. The harvested area and the paddy production in Percut Sei Tuan Sub-district in 2014 were about 10,592 ha and 63.72 ton with 3,610 ha of irrigated paddy fields and 1,616 ha of non-irrigated area [4].

The largest agriculture production center in Percut Sei Tuan Sub-district is scattered throughout Pematang Lalang Village, Cintai Damai, Tanjung Selamat, Tanjung Rejo, Percut and Cinta Rakyat Village. The existence of these agricultural barns was threatened due to the North Sumatra's government plan to turn Percut Sei Tuan as one of the area to be included in 10 development projects of Medan-Binjai-Deliserdang-Karo. The economic area of Percut Sei Tuan was designed in the form of industrial area and warehousing according to the planned expansion of Medan Industrial Park (Kawasan Industri Medan, KIM). The expansion of this industrial area has led to a change in the land ownership map and an increase in the land use conversion to warehousing and factory location in Percut Sei Tuan area, especially in Tanjung Selamat Village. The land use conversion continues to increase in Tanjung Selamat Village where the area of paddy fields in this village initially reached 600 hectares, but now only 200 hectares left [5].

Tanjung Selamat Village, Percut Sei Tuan Sub-district has a land area of $16.33 \mathrm{~km}^{2}$ and a population of 5,824 inhabitants. Farmer Groups "Pasar II" and "Mulia" are located in Tanjung Selamat Village, Percut Sei Tuan Sub-district. The Farmer Group "Pasar II" has a total membership of 30 farmers with a total paddy field area of 25 ha. The number of farmer group members and the size of agricultural land decreased by almost $50 \%$ within two years due to the land use conversion to industrial area. The Farmer Group "Mulia" has 76 members of farmers with 23 ha of paddy field area. The commodity cultivated by Farmers Groups "Pasar II" and "Mulia" is rice plants. The paddy productivity of Pasar II and Mulia farmer groups reached 6.2 tons/ha and 7 tons/ha, supported with technical irrigation. In a year, the farmers plant the crop twice, April-May (Planting Season A) and October-November (Planting Season B) in which they still use conventional techniques with single planting and single harvest.

One problem experienced by the farmer groups was the land use conversion resulting in reduced harvested area. Therefore, an effort or a technology are required to increase the productivity of land and harvest index. The farmers have not known salibu technology yet in which they can harvest 3 times with single planting. A few farmers can convert locally-specific organic materials into compost fertilizer and produce organic ZPT independently even though organic fertilizer and ZPT are one of the keys to implement salibu technology successfully. The farmers do not know the scale of farming analysis with salibu technology. 
This activity aims to increase the farmers' income with salibu technology because the farmers can harvest 2-3 times in one planting and to improve the farmers' understanding and knowledge about salibu technology and the manufacture of organic fertilizer and ZPT.

\section{Method}

Stages and methods of the community service were carried out in stages, such as:

1. Situation analysis of problems experienced by the partner (the farmer groups)

The problems were collected by the members of the community service by conducting interviews with the members of farmer groups. Then, the members of the community service and the farmer groups came to an agreement to decide an urgent problem to solve or to find a solution. The agreed problem was that there has been a reduction of almost $50 \%$ of the farmers' land, which initially was paddy field and then converted, which has a significant effect on the paddy production from Tanjung Selamat Village. The farmers did not have the knowledge of Salibu technology application and the technique to manufacture organic fertilizers and pesticides from local raw materials.

2. Solutions offered to solve the farmer groups' problems

After acknowledging and agreeing on the issues that must be solved, the community service members offered solutions according to the problems of the farmer groups. The solutions offered were creating demonstration plot (demplot), counseling and training on the application of salibu technology, manufacturing organic fertilizer with specific local organic raw materials into compost and organic pesticides independently, training and mentoring for the application of salibu technology in the farmer's field.

3. Implementing the program at the location

The members of the community service and the farmer groups both agreed and determined the timing for the program implementation at the site. The farmer groups participated by setting up the location of the program, inviting members of other farmer groups, and preparing materials required for the implementation of the community service in accordance with the agreed terms. On the other hand, the members of the community service prepared the counselling program materials about the application of salibu technology on rice plants.

\section{Results and Discussion}

The IbM program of salibu technology implementation to improve the welfare of the farmers in Tanjung Selamat Village had been implemented in accordance with the letter of agreement on 
the implementation of activities (SP2K) Number: 020 / LPPM / UNIVA / V / 2017. This IbM activity involved 4 lecturers and 3 students.

The IbM program of salibu technology implementation which was agreed between the members of the community service and the farmer groups in Tanjung Selamat Village consisted of:

1. Counseling on the Selection of N Fertilizer by Using Leaf Color Chart (LCC)

2. Counseling on the Importance of Bokashi Fertilizer and its Manufacturing Process

3. Counseling on Organic Pesticides and its Manufacturing Process

4. Counseling on Salibu and Ratun Technology

5. Training on Manufacture of Local Microorganisms from Organic Materials

6. Training on the Manufacture of Bokhashi Straw with Local Microorganisms

7. Training on the Application of Leaf Color Chart (LCC)

8. Training on the Manufacture of Organic Pesticides Based on Corynebacterium and Trichoderma

9. Implementation of Salibu Rice Technology on Demonstration Plot (Demplot)

Results from IbM activity about the implementation of salibu technology which was carried out in Tanjung Selamat Village were as follows:

1. The counseling and training activities had been completed, with lecturers as the source and farmers from the farmer groups who joined the community service as the participants.

2. The understanding and knowledge which the farmers obtained after the counseling and training were including:

- Farmers learnt how to use Leaf Color Chart (LCC) and how to determine the required amount of $\mathrm{N}$ fertilizer based on the leaf color chart reading

- Farmers learnt the importance and the manufacturing process of bokashi fertilizer

- Farmers learnt how to control crackle disease with organic pesticides based on corynebacterium and Trichoderma and how to implement it in the field.

- Farmers learnt the difference between salibu and ratun paddy and how to implement it in the field.

- Farmers learnt how to produce Local Microorganism (Mikro Organisme Local, MOL) from organic materials that are widely available around farmers and Local Microorganism from the cow's intestine.

- Farmers learnt how to produce simple pesticides from corynebacterium and Trichoderma.

3. Products manufactured in the community service program were including:

- Products of Local Microorganism from the cow's intestine. 
- Organic pesticide products made from Corynebacterium and Trichoderma.

- Paddy straw product that has been composted with Local Microorganism (bokashi).

4. The farmers participated in the IbM activities for the implementation of salibu technology received certificates and leaf color chart with the instructions for its use.

5. The implementation of salibu technology on $400 \mathrm{~m}^{2}$ demonstration plot had been completed and data obtained were as follows: ciherang varieties, 20.9 stems of tillers, the plant height of $71.8 \mathrm{~cm}$, the number productive panicles 9.5 fruit, yields $100 \mathrm{~kg} /$ rante (equals to 400 cubic meters of land).

Documentation of the IbM activities about the implementation of Salibu in Tanjung SelamatVillage which includes counselling activities, training, as well as making a demonstration plot for Salibu with the members of the community service and the farmer groups can be seen in Figure 1.

\section{Conclusion}

The implementation of salibu technology IbM activities had been fully implementedwith good results in accordance with predetennined activity schedule. The fanner groups gainedknowledge and skills on salibu technology, the production of organic fertilizer and pesticide, and could produce it independently. The farmer groups have also learnt how to apply salibu technology to paddy fields which resulted in increased land productivity per unit area and per unit of time, increased harvest index from 1 to 3 harvests a year, reduced farm worker wage costs, suppressed the farmers' habit of burning straw after harvest, saved the use of seed, labor, and time. 

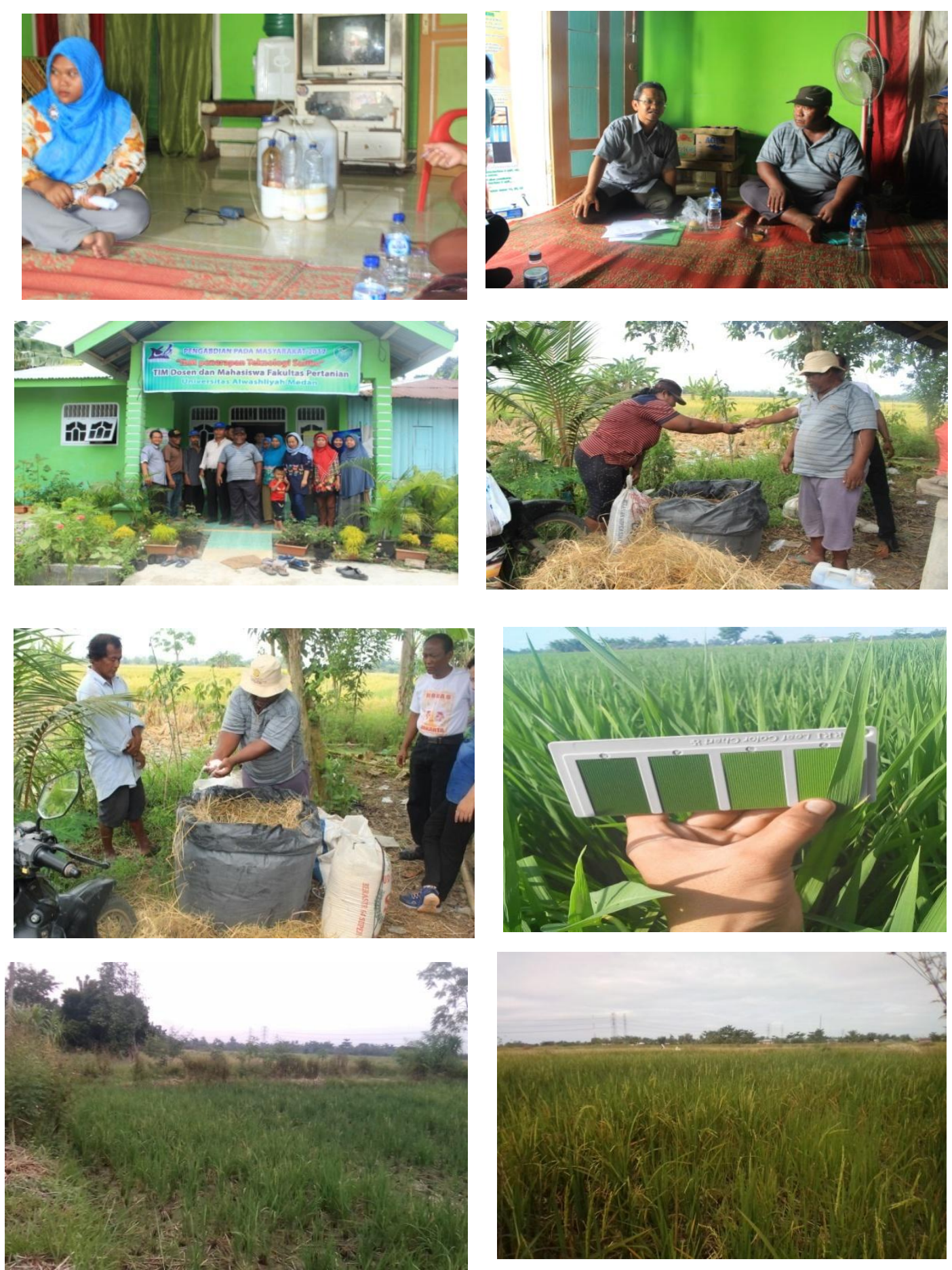

Figure 1. Documentation of the Activities

\section{Acknowledgement}

I would like to express my gratitude to the Directorate of Research and Community Service of the Ministry of Research, Technology, and Higher Education who has funded the activities of community service through science and technology schemes, Coordinator of Kopertis I NAD-SUMUT, Rector and Chairman of Lemlit UNIVA on the opportunities and facilities provided. 


\section{References}

[1] Ilham,N., K.Suradisastra, Tri Pranadji, A. Agustian, E. Lestari, H.,dan G. S. Hardono, 2008. Analisis Profil Petani dan Pertanian Indonesia. Pusat Analisis Sosial Ekonomi Pertanian dan Kebijakan Pertanian. Badan Litbang Pertanian Departemen Pertanian, Bogor.

[2] Pramono, M.S. 2015. Analisis Alih Fungsi Lahan Sawah Dan Prediksi Produksi Dan Konsumsi Beras Di Kabupaten Deli Serdang. Skripsi.Universitas Sumatera Utara.

[3] Erdiman, 2012. Teknologi Salibu Meningkatkan Produktivitas Lahan (3-6 Ton/Ha/Tahun) Dan Pendapatan Petani (Rp.15-25 Juta/Tahun), BPTP Sumatera Barat.

[4] BPS Deli Serdang, 2015. Statistik Daerah Kecamatan Percut Sei Tuan 2015. Badan Pusat Statistik Deli Serdang.

[5] Parsaoran, Z.2012. Lumbung Pangan Ditengah Arus Alih Fungsi Lahan Catatan Dari Percut Sei Tuan. Harian Medan Bisnis 30 Agustus 2012. 